\title{
Vegetative Ecological Characteristics of Restored Reed (Phragmites australis) Wetlands in the Yellow River Delta, China
}

\author{
Xuehong Wang $\cdot$ Junbao Yu $\cdot$ Di Zhou \\ Hongfang Dong · Yunzhao Li • Qianxin Lin • \\ Bo Guan · Yongli Wang
}

Received: 20 January 2011/ Accepted: 12 September 2011/Published online: 4 October 2011

(C) The Author(s) 2011. This article is published with open access at Springerlink.com

\begin{abstract}
In this study, we compared ecological characteristics of wetland vegetation in a series of restoration projects that were carried out in the wetlands of Yellow River Delta. The investigated characteristics include plant composition structure, species diversity and community similarity in three kinds of Phragmites australis wetlands, i.e. restored $P$. australis wetlands $(\mathrm{R} 1, \mathrm{R} 2, \mathrm{R} 3$ and $\mathrm{R} 4$ : restored in 2002, 2005, 2007 and 2009, respectively), natural $P$. australis wetland $(\mathrm{N})$ and degraded $P$. australis wetland (D) to assess the process of wetlands restoration. The coverage of the R1 was $99 \%$, which was similar to natural wetland. Among all studied wetlands, the highest and lowest stem density was observed in R1 and R2, respectively, Plant height and stem diameter show the same trend as $\mathrm{N}>\mathrm{R} 2>\mathrm{R} 1>\mathrm{R} 3>\mathrm{D}>\mathrm{R} 4$. Species diversity of restored $P$. australis wetlands became closed to natural wetland. Both species richness and Shannon-Wiener index had similar tendency: increased first and then decreased with restored time. The highest species richness and species diversity were observed in $\mathrm{R} 2$, while the lowest values of those parameters were found in natural $P$. australis
\end{abstract}

X. Wang · J. Yu ( $₫)$ · D. Zhou · H. Dong · Y. Li · B. Guan · Y. Wang

Laboratory of Coastal Wetland Ecology, Key Laboratory of Coastal Zone Environmental Processes, Yantai Institute of Coastal Zone Research, Chinese Academy of Sciences, Yantai, China

e-mail: junbao.yu@gmail.com; jbyu@yic.ac.cn

X. Wang - D. Zhou $\cdot$ H. Dong $\cdot$ Y. Li - B. Guan · Y. Wang Graduate University of the Chinese Academy of Sciences, Beijing, China

Q. Lin

Department of Oceanography and Coastal Sciences, Louisiana State University, Baton Rouge, LA, USA wetland. Similarity indexes between restored wetlands and natural wetland increased with the restoration time, but they were still less than $50 \%$. The results indicate that the vegetation of $P$. australis wetlands has experienced a great improvement after several years' restoration, and it is feasible to restored degraded $P$. australis wetlands by pouring fresh water into those wetlands in the Yellow River Delta. However, it is notable that costal degraded $P$. australis wetland in this region may take years to decades to reach the status of natural wetland.

Keywords Coastal wetland - Wetland restoration . Yellow River Delta · Vegetation characteristics · Species diversity

\section{Introduction}

There are about $5.94 \times 10^{4} \mathrm{~km}^{2}$ of coastal wetlands in China (Zhang and others 2005). Most of coastal wetlands have been severely disturbed due to their geographical and natural advantages for intensive economic activities. Wetland degradation, coastline erosion, soil salinization, biodiversity decreasing and barren lands increasing are a few consequences of disturbances (Conservation and others 1998; Steyer and Llewellyn 2000). It is estimated that more than half of the original wetlands in the word have been lost due to human activities (Mitsch 2005; Mitsch and Day 2006), therefore, effective protection and restoration for damaged and degraded wetlands are becoming more and more urgent (Bruland and Richardson 2005; Hopfensperger and others 2006; Orr and others 2007).

Wetlands restorations have attracted great attentions worldwide in last decades (Gilbert and others 2004; Gray and others 2002; Konisky and others 2006). To well 
understand the structure and function of the restored wetlands, researches on wetland degradation, restoration and reconstruction have become more important. Typically, wetland restoration focuses on repairing three key components: hydrology, soil and biology. The detailed components include water regime and chemistry (Bossio and others 2006; Niedermeier and Robinson 2007; Wilcox and others 2006), wildlife habitats (Zedler and Kercher 2005), vegetation composition and structure, coverage, biomass, plant diversity associated with restored species (Jin 2008; Phinn and others 1999; Walker and others 2004; Zedler 2005), soil microbial communities, and soil propagule bank (Ghorbani and others 2003; Grandin 2001; Robertson and James 2007; Smith and others 2002). Generally, the purposes of wetland restoration are to re-establish the ecological structure and functions of wetlands, links between biotic and abiotic components and to improve local biodiversity at all levels by considering the entire ecosystem (Gallego Fernández and García Novo 2007; Loomis and others 2000; Ruiz-Jaen and Aide 2005a; Zedler 2000).

Wetland restoration is a systematic (Kirk and others 2004) and long periodic (Matthews and others 2009) processes. Measurements of characteristics of vegetation, species diversity and wetland processes are used for wetland assessment (Breaux and others 2005; McCoy and Mushinsky 2002; Neckles and others 2002; Ruiz-Jaen and Aide 2005b; White and Walker 1997; Wilkins and others 2003). Vegetation is the basic component and the major producers of wetland ecosystem, and is the vital part of wetland structure and function. Wetland vegetation is influenced by many environmental factors such as water gradient, flow conditions, water transparence, biological competition and nutrients (Bart and Hartman 2000; Bodensteiner and Gabriel 2003). Ecological characteristics of vegetation are closely related to other factors and are the direct and first responding to restoration (Bart and Hartman 2000; Bodensteiner and Gabriel 2003; Keddy and Constabel 1986; Philipp and Field 2005). Therefore, studies of wetland vegetation changes during the restored process will help reveal the wetland ecological restoration processes.

The Yellow River Delta (YRD) is one of the most active land-ocean interaction regions among the large river deltas in the world. The YRD is called as the "Golden Triangle" due to its great exploitation potential and development of the YRD gets more and more attention. In recent years, suffering the impacts of interference of human activities and natural environmental changes, wetlands in the YRD have been deteriorated and lost considerably. Environmental deterioration and bio-diversity reduction are threatening birds habitats in the YRD (Ding and Li 2002; Shan 2007). Therefore, wetland restoration and reconstruction in the YRD play an important role in promoting sustainable development of economy and improving ecological environments. Phragmites australis is one of the most important, widespread and constructive wetland plant species over the YRD. There are about 2,600 ha $P$. australis wetland in the YRD. It provides staging, wintering and breeding sites for birds and may directly benefit from ecological restoration engineering for wetlands ( $\mathrm{Wu}$ and others 2009; Zhao and others 2005).

In this study, four $P$. australis wetlands which were restored at different times were selected and discussed their plant ecological characteristics, composition structure, species diversity and community similarity to determine how plant ecological characteristics and species composition changes over time. The objectives of the study are: (1) to reveal the vegetation succession pattern, (2) to provide scientific knowledge and information for restoration of $P$. australis wetlands, (3) and to support wetland restoration engineering and increase productive benefits.

\section{Material and Methods}

\section{Study Area}

The study area, the Yellow River Delta Natural Reserve (YRDNR) in Dongying city, Shandong province, China, is within the range of $37^{\circ} 35^{\prime} \mathrm{N}-38^{\circ} 12^{\prime} \mathrm{N}$ and $118^{\circ} 33^{\prime} \mathrm{E}-$ $119^{\circ} 20^{\prime} \mathrm{E}$. The YRDNR is located in the estuary of the Yellow River to the Bohai Sea, with an area of 153,000 ha. The YRDNR has been established to protect the newly formed wetland ecosystem and rare and endangered waterfowls. The climate in study area is warm temperate continental monsoon climate with distinctive seasons and rainy summer. The annual average temperature is $12.1^{\circ} \mathrm{C}$, the frost-free period lasts 196 days, annual average rainfall is $551.6 \mathrm{~mm}$ and annual average evaporation is $1,962 \mathrm{~mm}$. The reserve holds the most extensive, integrated and youngest wetland ecosystem (it formed since 1976) in the warm temperate zone of China (Ye and others 2004). Because of deposition of huge amount of sand and mud from Yellow River, it is estimated that about 1,300 ha territory land is formed here annually. A total of 296 bird species including over 200 migratory species have been recorded here. Among them, 10 species are listed as Class I of national protection wildlife such as red-crowned crane (Grus japonensis) and oriental white stork (Ciconia boyciana), and 49 species as Class II. A total of 400 plant species including 116 seed plants are recorded in the reserve. Common Seepweed, Strange Willow and Dogbane are widely distributed in the region. Wild Soybean, a Class II national protection plant, covers 3,800 ha. The YRDNR is the largest newly formed wetland along the coast of China covered by natural saline vegetation with $55.1 \%$ vegetation coverage. It has become an important over-wintering and 
breeding site for migrating birds in Northeast Asian Inland and Western Pacific Rim (Cui and others 2009).

In latest decades, because the dams and reservoirs facilitated water consumption and shifted the seasonal and annual variations in water consumption (Ren and others 2002) (Xu 2004), the water supply from Yellow River to the wetlands decrease greatly. As a result, substantial salinization in this region was becoming seriously, which results in the degradation of both wetlands and wildlife habitats. In order to improve wetland functions and habitats, a series of restoration projects were carried out in the region by local government in the YRDNR in 2002(R1), 2005(R2), 2007(R3), and 2009(R4), respectively. The restoration projects provide an excellent opportunity to study vegetation succession along restoration time. These four tested sites before degraded were covered by $P$. australia after decade's succession on new-born alluvial wetlands since 1976. The representative wetlands including natural wetland $(\mathrm{N})$, degraded wetland and restored wetland of R1, R2, R3 and R4 (Fig. 1) were selected for the study after field survey in 2009. The position of all restoration projects is $4 \mathrm{~km}$ south of the current watercourse of the Yellow River. Main process of the restoration project was designed to bring freshwater of Yellow River to degraded wetlands and resist saltwater intrusion to increase the self-regulatory capacity of wetland ecosystem and plants in four degraded wetlands were restored naturally.

\section{Data Collection and Calculation}

According to the pre-observation of vegetation, a fixed transect was set up in each wetland (total 6 transects). 40 quads $\left(1 \times 1 \mathrm{~m}^{2}\right)$ were selected randomly along the distribution of plants in each transect. The monthly data of plant coverage, plant density, plant height, stem diameter and plant species in each quad were recorded constantly during period of June to October in 2010.

The ecosystem's health situation can be well described by ecological characteristics of plants, species diversity of ecosystem and composition structure of plant community (Landau and others 1999; Neckles and others 2002). To estimate the restoration effects, it is important to reveal the species diversity, similarity level between different restored and reference communities and similarity of different restored communities (Lou and others 2007; Questad and Foster 2007; Ma and others 1995). In this study, Important value $(I V)$ was used to indicate the importance of species in a community $(I V>0.5$ as the dominant species, $0.3-0.5$ as the sub-dominant species); Richness Index and Shannon-Wiener index were used to describe species
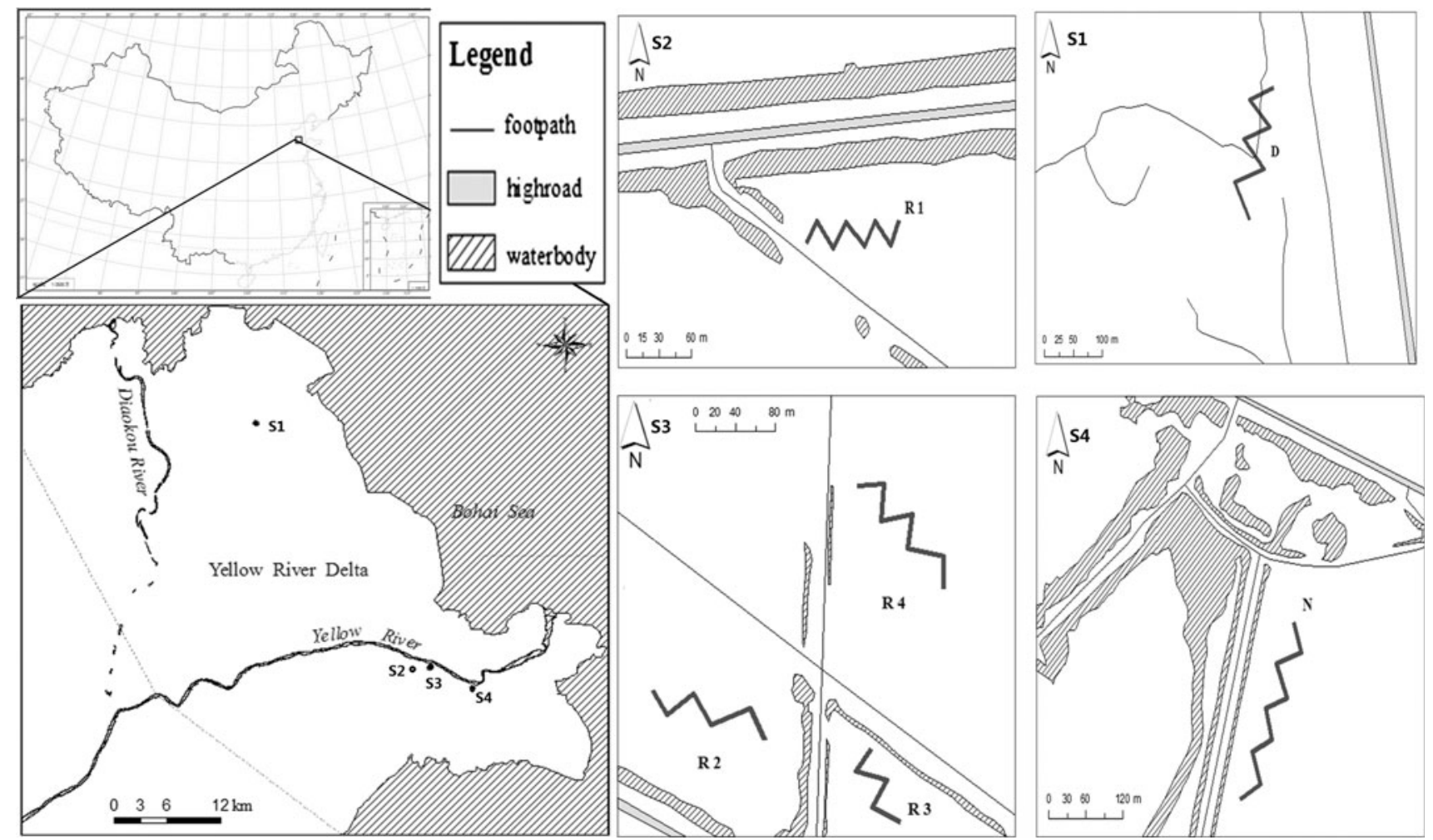

Fig. 1 Location map of Yellow River Delta and sample transects (40 quads for each transect) 
diversity; Sorenson's index were used to describe the similarity of different communities (Lou and others 2007; Ma and others 1995).

(1) Important Value (IV)

$I V=R H+R C+R F$

where: $I V$ is the important value; $R H$ is the relative density; $R C$ is the relative coverage; $R F$ is the relative frequency. In this paper, take $I V>0.5$ as the dominant species, $0.3-0.5$ as the sub-dominant species as a criteria (Landau and others 1999; Questad and Foster 2007).

(2) Richness Index $(R)$

$R=S$

(3) Diversity Index $(H)$, using Shannon-Wiener index

$H=-\sum_{i=1}^{n}\left(P_{i} \times \log P_{i}\right)$

where: $S$ is total number of species, $P_{i}$ is relative abundance of species " $i$ ", $n$ is total number of individuals of all species, $n$ is number of individuals of species " $i$ ".

(4) Similarity index (I), using Sorenson's index

$I=2 \mathrm{c} /(a+N) \times 100$

where $a$ is the number of species in wetland with a-year restoration; $N$ is the number of species in natural wetland; $\mathrm{c}$ is the number of common species between restored wetland and natural wetland.

\section{Results}

\section{Ecological Characteristics of $P$. australis Community}

Ecological characteristics of $P$. australis community primarily included plant coverage, stem density, height and stem diameter (Fig. 2). Coverage of the restored P. australis wetland increased gradually to similar with that of natural wetland with increasing restoration time using method of principal component analysis. Stem density showed as wavy line from D to N: first increased (D to R4), then decreased (R4 to R2), density decreased from R1 to N after it increased from R2 to R1. Density of R2 was the lowest, while R1 had the highest density. Plant heights and stem diameter had similar variation tendency in the order of $\mathrm{N}>\mathrm{R} 2>\mathrm{R} 1>\mathrm{R} 3>\mathrm{D}>\mathrm{R} 4$.

\section{Composition Structure of $P$. australis Community}

Four species belonging to 4 genera and 3 families were found in the R4. The community structure was composed by Gramineae, Polygonaceae and Convolvulaceae.

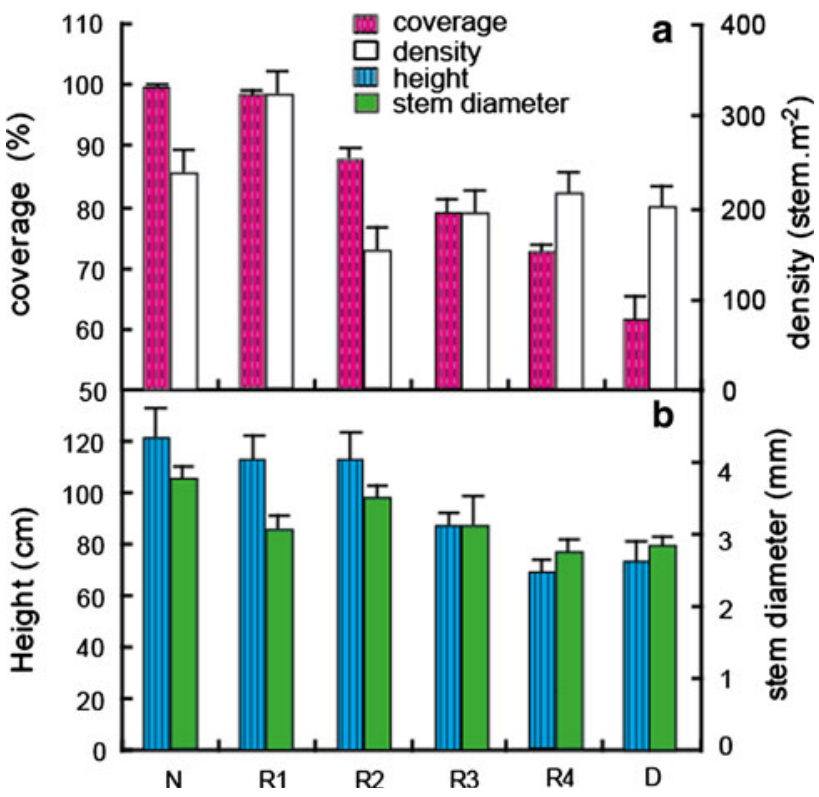

Fig. 2 Ecological characteristics of $P$. Australis community in natural wetland $(N)$, restored wetlands (restored in 2002: $R 1,2005$ : $R 2,2007: R 3$ and 2009: $R 4$ ) and degraded wetland (D), the column value is average of 40 squads in each site and the vertical bar stands for standard deviation

Fourteen species belonging to 14 genera and 10 families were found in R3. The community was composed mainly by Gramineae, Compositae, Polygonaceae and so on. There were 3 common species between R4 and R3, while Alopecurus aequalis were not observed in the rest 3 restored wetlands, and never appeared in natural reed wetland. Twenty-one species belonging to 21 genera and 17 families were found in R2. It was composed by Gramineae, Compositae, Leguminosae, Plantaginaceae and so on. There were 11 common species between R3 and R2. Ten species belonging to 10 genera and 9 families appear in R1. It was composed by Gramineae, Tamaricaceae, Legumnosae and so on. There were 7 common species between R2 and R1. It is clearly showed that the number of plant species first increased with increasing restoration time in the early stage (from the R4 to R2), and then decreased (from R2 to R1).

Our results of important Value of species (Table 1) showed that $P$. australis was the dominant species throughout the restored process. With the increase of restoration time (form R4 to R1), the important value of $P$. australis increased gradually from 0.5615 to 1.5508 , meanwhile the important value of other species decreased and the sub-dominant species changed greatly. At last, the $P$. australis became to be an absolute dominant species (without sub-dominant species) which was similar to the natural $P$. australis wetland. Further analysis, great changes of dominant species was found during the restoration process of R4 to R1. Species changed from plants adopting 


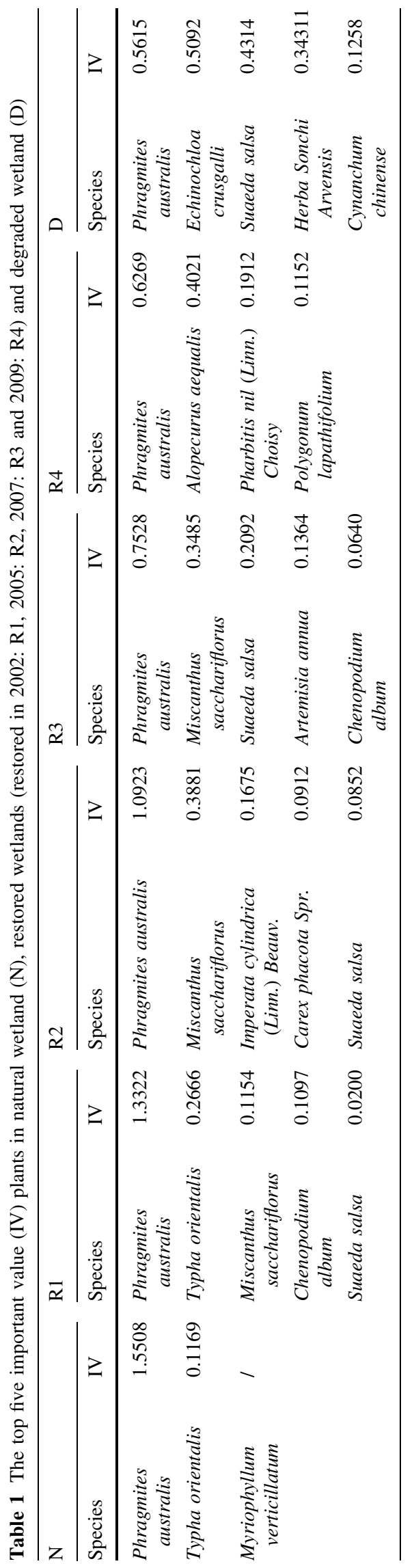

soils with lower water level (Alopecurus aequalis) and/or high salinity (Suaeda salsa) in R4 to aquatic plants and hydrophytes $(P$. australis and Typha orientalis) favoring suitable water level and/or low salinity in R1 (Table 1).

\section{Species Diversity}

Species richness and Shannon-Wiener index of the restored wetlands increased in the early restoration stage (from R4 to $\mathrm{R} 2$ ) and then decreased with increasing restoration time (from R2 to R1) (Fig. 3). The species richness and ShannonWiener index in restored wetlands were even higher than that in natural wetland. Both indices in R2 were the highest, followed by R3, D, R4, R1 and N, and their species richness were $6.2 \pm 1.09, \quad 5.8 \pm 0.24, \quad 4.8 \pm 0.62, \quad 2.8 \pm 0.32$, $2.7 \pm 0.65$ and $2.3 \pm 0.26$ species $\mathrm{m}^{-2}$, respectively. Species distribution of natural $P$. australis wetland was more uniform than other tested sites in which species number changed obviously among quads.

In order to verify differences of species richness among different wetlands,, the Multiple Mean Difference of species richness was adopted in the study. One-way analysis of variance (ANOVA) was used to test over all differences, while Least-significant difference (LSD) was selected to determine the difference between groups. Results showed that species richness between natural reed wetland and restored wetland was becoming close with increasing restoration time (Table 2). Differences of community species richness were significant $(P<0.05)$ by comparing the $\mathrm{R} 2, \mathrm{R} 3$ and $\mathrm{D}$ with $\mathrm{N}$, while there was no significant difference between $\mathrm{N}$ and $\mathrm{R} 1$ and $\mathrm{R} 4$. The $\mathrm{R} 1$ had significant differences comparing with the $\mathrm{R} 2, \mathrm{R} 3$, and $\mathrm{D}(P<0.05)$. The $\mathrm{R} 2$ and $\mathrm{R} 3$ had significant differences by comparing with the R4 $(P<0.05)$, but did not show any significant changes by compared to the $\mathrm{D}$. The R4 had significant changes versus D (Table 2).

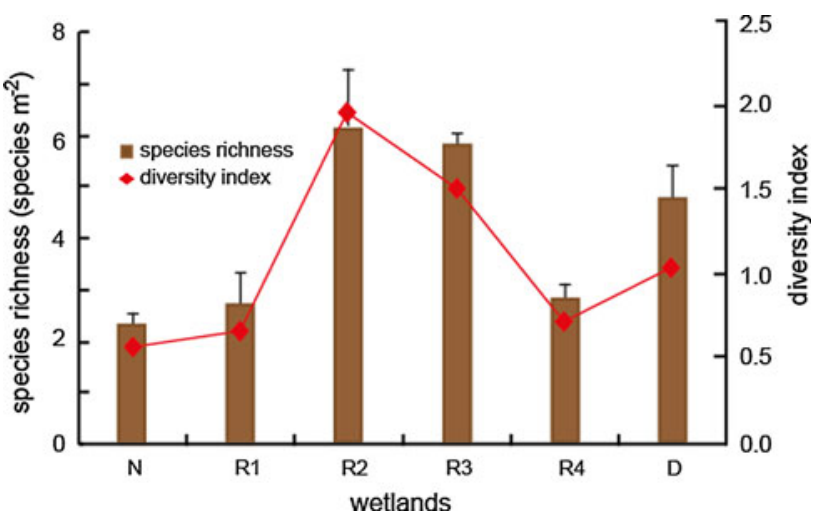

Fig. 3 The mean species richness and Shannon-Wiener index in different $P$. australis wetland, the column value is average of 40 squads in each site and the vertical bar stands for standard deviation ( $N$ natural wetland; $R 1, R 2, R 3$ and $R 4$ restored wetlands in 2002, 2005, 2007 and 2009, respectively; $D$ degraded wetland, vertical bar stands for standard deviation) 
Table 2 Species richness multiple comparisons among wetlands
* The mean difference is significant at 0.05 level $N$ natural wetland; $R 1, R 2, R 3$ and $R 4$ restored wetlands in 2002, 2005, 2007 and 2009, respectively; $D$ degraded wetland

\begin{tabular}{|c|c|c|c|c|c|}
\hline \multirow[t]{2}{*}{ (I) } & \multirow[t]{2}{*}{$(\mathrm{J})$} & \multirow{2}{*}{$\begin{array}{l}\text { Mean difference } \\
(I-J)\end{array}$} & \multirow[t]{2}{*}{ St. error } & \multicolumn{2}{|c|}{$95 \%$ confidence interval } \\
\hline & & & & Lower bound & Upper bound \\
\hline \multirow[t]{5}{*}{$\mathrm{N}$} & $\mathrm{R} 1$ & -0.55556 & 0.94608 & -2.4578 & 1.3467 \\
\hline & $\mathrm{R} 2$ & $-3.77778^{*}$ & 0.94608 & -5.68 & -1.8756 \\
\hline & R3 & $-3.44444^{*}$ & 0.94608 & -5.3467 & -1.5422 \\
\hline & $\mathrm{R} 4$ & -0.33333 & 0.94608 & -2.2355 & 1.5689 \\
\hline & $\mathrm{D}$ & $-2.66667^{*}$ & 0.94608 & -4.5689 & -0.7645 \\
\hline \multirow[t]{4}{*}{$\mathrm{R} 1$} & $\mathrm{R} 2$ & $-3.22222^{*}$ & 0.94608 & -5.1244 & -1.32 \\
\hline & R3 & $-2.88889^{*}$ & 0.94608 & -4.7911 & -0.9867 \\
\hline & R4 & 0.22222 & 0.94608 & -1.68 & 2.1244 \\
\hline & $\mathrm{D}$ & $-2.11111^{*}$ & 0.94608 & -4.0133 & -0.2089 \\
\hline \multirow[t]{3}{*}{$\mathrm{R} 2$} & R3 & 0.33333 & 0.94608 & -1.5689 & 2.2355 \\
\hline & $\mathrm{R} 4$ & $3.44444 *$ & 0.94608 & 1.5422 & 5.3467 \\
\hline & $\mathrm{D}$ & 1.11111 & 0.94608 & -0.7911 & 3.0133 \\
\hline \multirow[t]{2}{*}{ R3 } & R4 & $3.11111 *$ & 0.94608 & 1.2089 & 5.0133 \\
\hline & $\mathrm{D}$ & 0.77778 & 0.94608 & -1.1244 & 2.68 \\
\hline $\mathrm{R} 4$ & $\mathrm{D}$ & $-2.33333 *$ & 0.94608 & -4.2355 & -0.4311 \\
\hline
\end{tabular}

Similarity Index

Community Similarity Index could indicate the similarity level between different restored and reference communities (Natural wetland in the study). Results showed that the similarity increased with the restoration time, except for R4 (Fig. 4). Similarity between R4 and N was high, mainly results from fewer plant species found in R4 than the other wetlands. It indicated that plant communities were becoming more and more similar to the natural community with the restoration time. However, we should note that the similarity was still very low (less than $50 \%$ ) even after several years' restoration in Yellow River Delta.

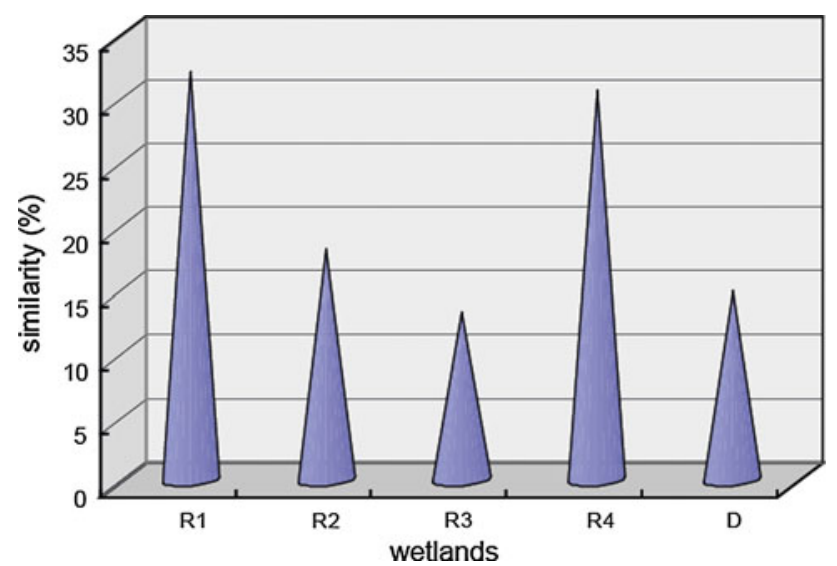

Fig. 4 Similarity of restored and degraded $P$. australis wetlands to natural wetland $(R 1, R 2, R 3$ and $R 4$ restored wetlands in 2002, 2005, 2007 and 2009, respectively; $D$ degraded wetland)

\section{Discussions}

The ultimate goal of wetland restoration is to create a selfsupporting ecosystem that can resist to perturbation without further assistance. Therefore the criterion to evaluate success is critical for restoration (Ruiz-Jaen and Aide 2005a, b). Previous studies suggested that restoration success could be evaluated primarily by three parts: vegetation characteristics (Walters 2000; Wilkins and others 2003), species diversities (McCoy and Mushinsky 2002; Passell 2000) and ecosystem processes (Cui and others 2009; Rhoades and others 1998). Generally ecologically functional processes are slow to recover in comparison with vegetation structure and diversity, so we focus on vegetation characteristics, structure and species diversities in the presentation.

In this study, ecological characteristics of $P$. australis population gradually changed to close to those in natural wetland during the restoration process in the YRD (Fig. 2). Table 1 suggested that Gramineae, Compositae and Polygonacea were the most important families in all studied wetlands and, species of Compositae ever exceeded the Gramineae with restoration time increasing, while P. australis, the main Gramineae, was always the dominant species and colonized constantly. Results about species diversity (including species richness and Shannon-Wiener index) showed similar tendency: the species diversity in restored wetland decreased gradually to close to the natural wetland after increases from R4 to R2 (Fig. 3). This phenomenon can be explained by plant competition. Plants species, rapidly expanding and colonizing new zones of the 
salt marsh, can consume soil water and nutrients. Moreover, a dense stand of one species can reduce the access to light for seedlings of other species, thus limiting their development (Ungar 1998). With development of P. australis, other species would have suffered from intensive competition exerted by this species (Budelsky and Galatowitsch 2000). Our results are general agreement that a consequence of the disappearance of the plant zonation pattern in wetlands is a deterioration of the spatial structure of the ecosystem and a decrease in habitat diversity (Mitsch and Gosselink 2000). Some studies suggested that an aggressive plant could impair the spatial heterogeneity and biodiversity of vegetation (Green and Galatowitsch 2002). In our study, natural $P$. australis wetland as a reference selected in YRD had its regional characteristics, such as low species diversity. Even though $P$. australis usually formed a mono-species community in some locations, it can still sustain itself without assistance. So in the YRD, during the process of $P$. australis community restoration, increasing $P$. australis could be considered as a good phenomenon.

Wetland restoration is an important and complex ecological process, and is related to many factors, including ecology, soil science, geography, hydrology, etc. (Gattie and others 2003; Hastings and others 2007). In this study, a total of 28 species belonging to 28 genera and 21 families existed in the four restored wetlands and showed a series of changes in vegetation with the restored time increasing (Fig. 3). Table 1 showed that at the beginning of restoration in 2009 (R4), pioneer species were plants that adapted to soil of high soil salinity (such as $S$. salsa) and lower water level (Dong and others 2010; Guan and others 2011), while some hygrophyte species (such as $P$. australis) exhibited poor growth status (Fig. 2). Subsequently, vegetation changed to dominant specie favoring low salinity and suitable water level, such as $P$. australis and T. orientalis. Finally, vegetation composition structure and characteristics are more similar to the natural wetland. However, compared with previous research (Cui and others 2009), numbers of species were considerably low in this study, even much lower than that in the pre-damaged wetland.

Wetland vegetation could rapidly respond to alterations in environmental conditions (Tiner 1999), the fluctuating hydrological regime (Mitsch 2005) and salinity (Perry and Hershner 1999) have been considered as two major factors that control its distribution pattern. Water depth is considered to be the most significant factor controlling the establishment of wetland species. In the YRD, hydrological regime is a critical factor controlling success of restoration. It is important to effectively use water during regulation and control of flow and sediment in the Yellow River Estuary. Once introducing water into test areas, surface water depth varied from $0 \mathrm{~cm}$ to more than $100 \mathrm{~cm}$ because of microtopography, it was even drought in local area. This can explain the plant distribution pattern: species richness was also not same in each quad (Fig. 3). However, very significantly, fresh water was short supply in North China, to restore more wetlands with less water are critical. Therefore, installment of water gradients and flooding time need further and more precise studies in the future. Changes in plant species composition are response to dramatic changes of soil salinity. The result showed that salinity (EC represents soil salinity in this presentation) decreased gradually along wetland restoration (Fig. 5a), soil condition became more suitable for vegetation development. Meanwhile, $\mathrm{pH}$ value showed complicated trend (Fig. 5b) comparing with characteristics and species diversity. $\mathrm{pH}$ value and $\mathrm{EC}$ value showed significant correlation $(P<0.01)$ with ecological characteristics. EC value showed significant correlation $(P<0.01)$ with species diversity, while $\mathrm{pH}$ value did not have significant correlation with species diversity $(P=0.738>0.05)$. This result indicated "salinity" was much more important factor than "alkali" ( $\mathrm{pH}$ value) to effect vegetation restoration in the YRD.

Seed bank was also considered to be another important factor in wetland restoration (Brown 1998), it will provide seed sources for plant development. Some authors also pointed out that the species composition of the aboveground vegetation is sometimes different from the seed banks (Liu and others 2005). However, there was little previous study on seed bank in YRD. The role of seed bank

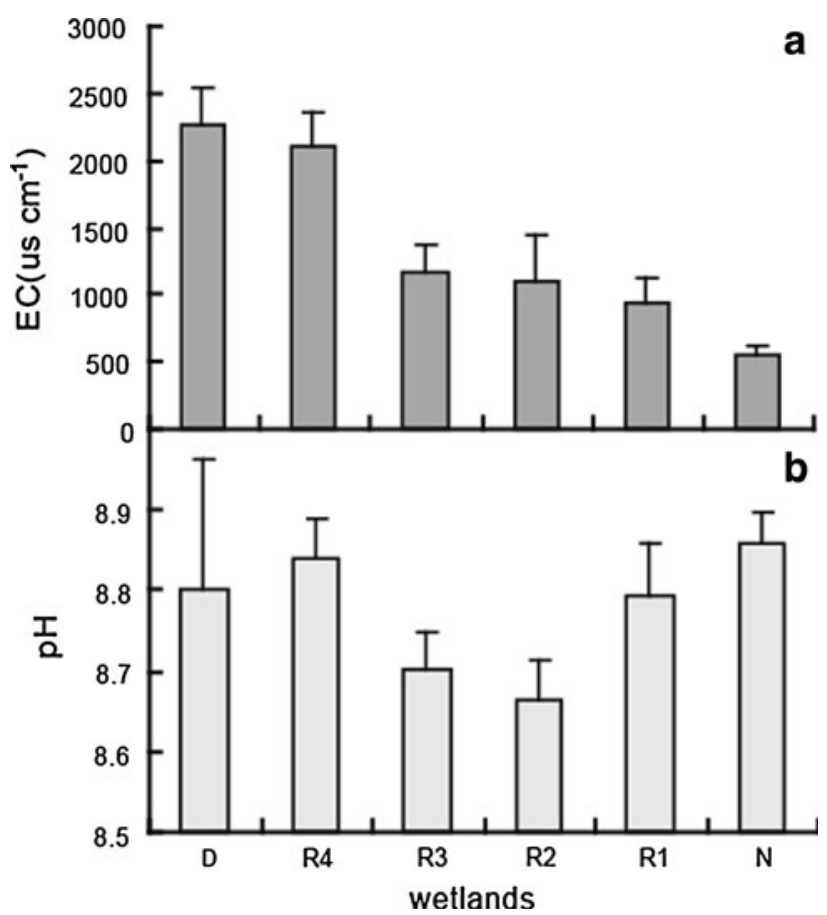

Fig. $5 \mathrm{pH}$ value (a) and EC value (b) in different studied wetlands of Yellow River Delta $(R 1, R 2, R 3$ and $R 4$ restored wetlands in 2002, 2005, 2007 and 2009, respectively; $D$ degraded wetland; $N$ natural wetland) 
in wetland restoration in YRD is still unclear, and it need further study in the future. It must be a hot pot to support wetlands restoration and management.

Wetland Restoration is also a process of community succession that requires time for development (Avis 1995; Zhang and others 2005). Zhang and Dong (2010) reported that restoration processes are mainly influenced by the period of restored time, especially for natural restoration. Study results indicated that there were great difference $(P<0.05)$ in the vegetation characteristics between natural wetlands, degraded wetlands and the restored wetlands (Tables 1, 2; Figs. 2, 3). Figure 4 indicated that plant communities were becoming more and more similar to the natural community with the restoration time. However, community similarity was still less than $50 \%$ after several years' restoration. Therefore, it indicates that the degraded $P$. australis wetlands in the YRD would take years to decades restoration to reach the status of natural reed wetland. Besides, project sustainability (fresh water input) is also suggested in future wetlands restoration.

Acknowledgments We are grateful for support from the Chinese Academy of Sciences (Grant \# kzcx2-yw-223; kzcx2-yw-359); National Natural Science Foundation for Distinguished Young Scholar of Shandong Province (No. JQ201114); Project of National Science \& Technology Pillar Program in "12th Five Year" period (2011BAC02B01); the CAS/SAFEA international partnership program for creation research team; The National Commonweal (Agricultural) research project (200903001); the National Natural Science Foundation of China (40873062); the 100 Talents Program of the Chinese Academy of Sciences and the Science and Technology Planning Program of Shandong Province (No. 2008GG20005006, 2008GG3NS07005). Three anonymous referees are appreciated for constructive comments and suggestions, which are helpful for us to improve our manuscript.

Open Access This article is distributed under the terms of the Creative Commons Attribution Noncommercial License which permits any noncommercial use, distribution, and reproduction in any medium, provided the original author(s) and source are credited.

\section{References}

Avis A (1995) An evaluation of the vegetation developed after artificially stabilizing South African coastal dunes with indigenous species. Journal of Coastal Conservation 1(1):41-50

Bart D, Hartman J (2000) Environmental determinants of Phragmites australis expansion in a New Jersey salt marsh: an experimental approach. Oikos 89(1):59-69

Bodensteiner L, Gabriel A (2003) Response of mid-water common reed stands to water level variations and winter conditions in Lake Poygan, Wisconsin, USA. Aquatic Botany 76(1):49-64

Bossio D, Fleck J, Scow K, Fujii R (2006) Alteration of soil microbial communities and water quality in restored wetlands. Soil Biology and Biochemistry 38(6):1223-1233

Breaux A, Cochrane S, Evens J, Martindale M, Pavlik B, Suer L, Benner D (2005) Wetland ecological and compliance assessments in the San Francisco Bay Region, California, USA. Journal of Environmental Management 74(3):217-237
Brown S (1998) Remnant seed banks and vegetation as predictors of restored marsh vegetation. Botany 76(4):620-629

Bruland G, Richardson C (2005) Hydrologic, edaphic, and vegetative responses to microtopographic reestablishment in a restored wetland. Restoration Ecology 13(3):515-523

Budelsky R, Galatowitsch S (2000) Effects of water regime and competition on the establishment of a native sedge in restored wetlands. Journal of Applied Ecology 37(6):971-985

Conservation L, Force R, Conservation W, Authority R (1998) Coast 2050: toward a sustainable coastal Louisiana. Louisiana Department of Natural Resources, Baton Rouge

Cui B, Yang Q, Yang Z, Zhang K (2009) Evaluating the ecological performance of wetland restoration in the Yellow River Delta, China. Ecological Engineering 35(7):1090-1103

Ding Z, Li M (2002) The influence of flow interruptions in the Yellow River on the Yellow River Delta. Journal of Zaozhuang University 19(05):85-87, 96

Dong H, Yu J, Sun Z, Mu X, Chen X, Peili M, Wu C, Guan B (2010) The spatial distribution characteristics of organic carbon in the soil-plant systems in the Yellow River estuary tidal flat wetland. Environmental Science 31(6):1594-1599

Gallego Fernández J, García Novo F (2007) High-intensity versus low-intensity restoration alternatives of a tidal marsh in Guadalquivir estuary, SW Spain. Ecological Engineering 30(2): $112-121$

Gattie D, Smith M, Tollner E, McCutcheon S (2003) The emergence of ecological engineering as a discipline. Ecological Engineering 20(5):409-420

Ghorbani J, Das P, Das A, Hughes J, McAllister H, Pallai S, Pakeman R, Marrs R, Le Duc M (2003) Effects of restoration treatments on the diaspore bank under dense Pteridium stands in the UK. Applied Vegetation Science 6(2):189-198

Gilbert A, van Herwijnen M, Lorenz C (2004) From spatial models to spatial evaluation in the analysis of wetland restoration in the Vecht river basin. Regional Environmental Change 4(2): $118-131$

Grandin U (2001) Short-term and long-term variation in seed bank/ vegetation relations along an environmental and successional gradient. Ecography 24(6):731-741

Gray A, Simenstad C, Bottom D, Cornwell T (2002) Contrasting functional performance of juvenile salmon habitat in recovering wetlands of the Salmon River estuary, Oregon, USA. Restoration Ecology 10(3):514-526

Green E, Galatowitsch S (2002) Effects of Phalaris arundinacea and nitrate- $\mathrm{N}$ addition on the establishment of wetland plant communities. Journal of Applied Ecology 39(1):134-144

Guan B, Yu J, Xie W, Chen X, Wang X (2011) The ecological effects of Suaeda + salsa on repairing heavily degraded coastal salinealkaline wetlands in the Yellow River Delta. Acta Ecologica Sinica 31(14): 1753-1758

Hastings A, Byers J, Crooks J, Cuddington K, Jones C, Lambrinos J, Talley T, Wilson W (2007) Ecosystem engineering in space and time. Ecology Letters 10(2):153-164

Hopfensperger K, Engelhardt K, Seagle S (2006) The use of case studies in establishing feasibility for wetland restoration. Restoration Ecology 14(4):578-586

Jin C (2008) Biodiversity dynamics of freshwater wetland ecosystems affected by secondary salinisation and seasonal hydrology variation: a model-based study. Hydrobiologia 598(1):257-270

Keddy P, Constabel P (1986) Germination of ten shoreline plants in relation to seed size, soil particle size and water level: an experimental study. The Journal of Ecology 74(1):133-141

Kirk JA, Wise WR, Delfino JJ (2004) Water budget and costeffectiveness analysis of wetland restoration alternatives: a case study of Levy Prairie, Alachua County, Florida. Ecological Engineering 22(1):43-60 
Konisky R, Burdick D, Dionne M, Neckles H (2006) A regional assessment of salt marsh restoration and monitoring in the Gulf of Maine. Restoration Ecology 14(4):516-525

Landau D, Prowell D, Carlton CE (1999) Intensive versus long-term sampling to assess Lepidopteran diversity in a southern mixed mesophytic forest. Annals of the Entomological Society of America 92(3):435-441

Liu G, Zhou J, Li W, Cheng Y (2005) The seed bank in a subtropical freshwater marsh: implications for wetland restoration. Aquatic Botany 81(1):1-11

Loomis J, Kent P, Strange L, Fausch K, Covich A (2000) Measuring the total economic value of restoring ecosystem services in an impaired river basin: results from a contingent valuation survey. Ecological Economics 33(1):103-117

Lou Y, Zhao K, Ma K (2007) Change in floristic composition and species diversity of plant comm unity along environment gradient in Honghe National Nature Reserve, China. Acta Ecologica Sinica 27(9):3883-3891

Ma K, Huang J, Yu S, Chen L (1995) Plant community diversity in Dongling Mountain, Beijing, China II. Species richness, evenness and species diversities. Acta Ecologica Sinica 15(3):268-277

Matthews J, Spyreas G, Endress A (2009) Trajectories of vegetationbased indicators used to assess wetland restoration progress. Ecological Applications 19(8):2093-2107

McCoy E, Mushinsky H (2002) Measuring the success of wildlife community restoration. Ecological Applications 12(6):1861-1871

Mitsch W (2005) Wetland creation, restoration, and conservation: a wetland invitational at the Olentangy River Wetland Research Park. Ecological Engineering 24:243-251

Mitsch WJ, Day JJW (2006) Restoration of wetlands in the Mississippi-Ohio-Missouri (MOM) River Basin: experience and needed research. Ecological Engineering 26(1):55-69

Mitsch W, Gosselink J (2000) The value of wetlands: importance of scale and landscape setting. Ecological Economics 35(1):25-33

Neckles H, Dionne M, Burdick D, Roman C, Buchsbaum R, Hutchins E (2002) A monitoring protocol to assess tidal restoration of salt marshes on local and regional scales. Restoration Ecology 10(3): 556-563

Niedermeier A, Robinson J (2007) Hydrological controls on soil redox dynamics in a peat-based, restored wetland. Geoderma 137(3-4):318-326

Orr C, Stanley E, Wilson K, Finlay J (2007) Effects of restoration and reflooding on soil denitrification in a leveed Midwestern floodplain. Ecological Applications 17(8):2365-2376

Passell H (2000) Recovery of bird species in minimally restored Indonesian tin strip mines. Restoration Ecology 8(2):112-118

Perry J, Hershner C (1999) Temporal changes in the vegetation pattern in a tidal freshwater marsh. Wetlands 19(1):90-99

Philipp K, Field R (2005) Phragmites australis expansion in Delaware Bay salt marshes. Ecological Engineering 25(3):275-291

Phinn S, Stow D, Van Mouwerik D (1999) Remotely sensed estimates of vegetation structural characteristics in restored wetlands, Southern California. Photogrammetric Engineering and Remote Sensing 65(4):485-493

Questad EJ, Foster BL (2007) Vole disturbances and plant diversity in a grassland metacommunity. Oecologia 153(2):341-351

Ren L, Wang M, Li C, Zhang W (2002) Impacts of human activities on river runoff in the northern area of China. Journal of Hydrology 261:204-217

Rhoades C, Eckert G, Coleman D (1998) Effect of pasture trees on soil nitrogen and organic matter: implications for tropical montane forest restoration. Restoration Ecology 6(3):262-270

Robertson H, James K (2007) Plant establishment from the seed bank of a degraded floodplain wetland: a comparison of two alternative management scenarios. Plant Ecology 188(2):145-164
Ruiz-Jaen M, Aide T (2005a) Restoration success: how is it being measured? Restoration Ecology 13(3):569-577

Ruiz-Jaen M, Aide T (2005b) Vegetation structure, species diversity, and ecosystem processes as measures of restoration success. Forest Ecology and Management 218(1-3):159-173

Shan K (2007) Theory, methodology and practices of wetland ecological restoration in Yellow River Delta Nature Reserve. Wetland Science \& Management 3(04):16-20

Smith R, Shiel R, Millward D, Corkhill P, Sanderson R (2002) Soil seed banks and the effects of meadow management on vegetation change in a 10-year meadow field trial. Journal of Applied Ecology 39(2):279-293

Steyer GD, Llewellyn DW (2000) Coastal wetlands planning, protection, and restoration act: a programmatic application of adaptive management. Ecological Engineering 15(3-4):385-395

Tiner R (1999) Wetland indicators: a guide to wetland identification, delineation, classification, and mapping. CRC, Boca Raton

Ungar I (1998) Are biotic factors significant in influencing the distribution of halophytes in saline habitats? The Botanical Review 64(2):176-199

Walker K, Stevens P, Stevens D, Mountford J, Manchester S, Pywell $\mathrm{R}$ (2004) The restoration and re-creation of species-rich lowland grassland on land formerly managed for intensive agriculture in the UK. Biological Conservation 119(1):1-18

Walters B (2000) Local mangrove planting in the Philippines: are fisherfolk and fishpond owners effective restorationists? Restoration Ecology 8(3):237-246

White P, Walker J (1997) Approximating nature's variation: selecting and using reference information in restoration ecology. Restoration Ecology 5(4):338-349

Wilcox D, Sweat M, Carlson M, Kowalski K (2006) A water-budget approach to restoring a sedge fen affected by diking and ditching. Journal of Hydrology 320(3-4):501-517

Wilkins S, Keith D, Adam P (2003) Measuring success: evaluating the restoration of a grassy eucalypt woodland on the Cumberland Plain, Sydney, Australia. Restoration Ecology 11(4):489-503

Wu D, Liu J, Wang W, Ding W, Wang R (2009) Multiscale analysis of vegetation index and topographic variables in the Yellow River Delta of China. Chinese Journal of Plant Ecology 33(02): 237-245

Xu J (2004) A study of anthropogenic seasonal rivers in China. Catena 55:17-32

Ye QH, Liu GH, Tian GL, Chen SL, Huang C, Chen SP, Liu QS, Chang J, Shi Y (2004) Geospatial-temporal analysis of land-use changes in the Yellow River Delta during the last 40 years. Science in China Series D-Earth Sciences 47(11):1008-1024

Zedler JB (2000) Progress in wetland restoration ecology. Trends in Ecology \& Evolution 15(10):402-407

Zedler J (2005) Restoring wetland plant diversity: a comparison of existing and adaptive approaches. Wetlands Ecology and Management 13(1):5-14

Zedler J, Kercher S (2005) Wetland resources: status, trends, ecosystem services, and restorability. Annual Review of Environment and Resources 30:39-74

Zhang J, Dong Y (2010) Factors affecting species diversity of plant communities and the restoration process in the loess area of China. Ecological Engineering 36(3):345-350

Zhang X, Li P, Li P, Xu X (2005) Present conditions and prospects of study on coastal wetlands in China. Advances in Marine Science 23(1):87-95

Zhao X, Cui B, Yang Z (2005) A study of the lowest ecological water level of Baiyangdian Lake. Acta Ecologica Sinica 25(5): 1033-1040 